\title{
PROFILE OF LYCOPENE UV-SPECTRA OF LACTIC ACID BACTERIA FERMENTED MILK-TOMATO PASTE
}

\author{
Isnaeni $^{1 *}$, Nailatul Hidayah ${ }^{1}$, Utari Ardiningdyah ${ }^{1}$, Izza Rahmi Hidayah ${ }^{1}$ \\ ${ }^{1}$ Faculty of Pharmacy, Universitas Airlangga, Dharmawangsa Dalam, Surabaya 60286, Indonesia
}

Received March 13, 2019; Accepted May 10, 2019

\begin{abstract}
Lycopene is one of the famous ingredients in tomatoes, because of its important role as a potent anti-oxidant. Besides being consumed as fresh fruit, tomato paste can be combined with probiotic fermented milk to increase its health benefits. Probiotics are lactic acid bacteria (LAB), which when consumed in sufficient quantities will benefit health. Probiotic fermented milk is reported to have various properties including anti-microbial, antioxidant, immunomodulatory and anti-cancer, so the combination with tomato paste is expected to increase its benefits for health. This research aimed to study the effect of probiotic fermented milk on the content of tomato paste lycopene. Lactobacillus acidophillus, Lactobacillus bulgaricus, and Lactobacillus casei were used as mixed probiotic cultures. It was found that at the ratio of 2:8 for the LAB fermented milk and tomato paste, the highest lycopene drive was obtained by spectrophotometric measurement at 663 , 645,505 , and $453 \mathrm{~nm}$. Determination of the lycopene content was performed according to the Nagata and Yamashita simple methods. In addition, the lycopene content in the LAB fermented milk-tomato paste was greater than the content in the tomato paste without fermented milk addition and was tested stable after storage for 14 days.
\end{abstract}

Keywords: antioxidant; lycopene; probiotic fermented milk; tomato paste

\section{INTRODUCTION}

Yogurt is a product that is obtained from pasteurized milk and then fermented with bacteria to obtain a characteristic acidity, odor and taste with or without the addition of other permissible ingredients (Anonim, 2009). Lactobacillus spp. are the most predominate probiotic bacteria, and some of them are commonly used in making yogurt such as Lactobacillus bulgaricus, Lactobacillus acidophillus, Lactobacills casei, and Streptococcus thermophillus. Lactic acid bacteria (LAB) are the most important probiotics because of its beneficial effects on the human digestive tract or other activities, such as immunomodulatory (Isnaeni, 2016). Rajarajan et al. (2018) evaluated antimicrobial activity and probiotic potential of Lactobacillus strains against some human pathogens. Isnaeni and Mertaniasih (2015) reported the growth inhibitory activities of mixed culture LAB against MRSA and ESBL. Inhibitory activity of LAB fermented milk and tomato juice combination against Escherichia coli and Staphylococcus aureus has been reported (Hidayah, 2014). Wang et al. (2017) reviewed antioxidant activity of the probiotic, although its mechnisms of action have not been completely understood.

Various food matrices have been developed with probiotics and were reported. With different technologies such as microencapsulation, nanoparticle (Sugiyartono, 2014; Sholeha et al., 2014) and continuous fermentation, the probiotic will become an important ingredient in the functional foods (Soccol et al., 2010). Yogurt product is one of the popular probiotic fermentation foods, found on the market in various forms including food, drinks and ice cream. The yogurt products are very popular in countries with four seasons, but in 
Indonesia the fermented milk containing LAB has also been popular, especially in cold climate cities with surplus milk dairy products. Yogurt preparations are often combined with fruits such as soursop, mangoes, avocados, durians, oranges, and others. Various tomatoyogurt combinations include yogurt curry tomatoes, tomato yogurt sauce, yogurt smoothie tomatoes, and salad tomatoes with chili yogurt and even for cosmetic preparations as a tomato face mask. Kaur et al. (2016) studied fermentation of tomato juice by probiotic LAB. They demonstrated that Lactobacillus acidophylus, Lactobacillus plantarum, and Lactobacillus casei probiotics showing the ability to use the tomato juice as raw material to increse viability count.

Tomatoes (Lycopersicon esculentum) and its products contain lycopene, predominant carotenoid $(5.7-26.3 \mathrm{mg} / \mathrm{kg}$ ) and an antioxidant which plays an important role in health and disease reduction (Erge and Karadeniz, 2011). The bioactive compounds in tomato fruit are carotenoid, phenolic and L-ascorbic acid; which act as antioxidants, which has a protective effect against various forms of cancer and cardiovascular diseases (Kopsel et al., 2006). There are various manners of tomato processing to gain several kinds of tomato products, such as tomato juice, tomato paste, tomato boiled sauce, tomato ketchup with different specifications and lycopene content (Alda et al., 2009). The lycopene content in tomato paste is higher than fresh tomatoes. Lycopene contents of fresh, sundried and canned tomatoes were found to be $1.74, \quad 5.51$ and $3.55 \mathrm{mg} / 100 \mathrm{~g}$, showing different antioxidant activities (Karakaya and Yilmaz, 2007).

This research was a breakthrough to make Nutraceutical food from tomatoes products combined with LAB fermented milk derived from LAB probiotics mixed culture (Lactobacillus acidophilus, Lactobacillus bulgaricus, and Lactobacillus casei). A nutraceutical is a food or part of food that provides health benefits including prevention and treatment of diseases. From this definition, nutraceuticals can be in the form of isolated nutrients, food supplements, herbal products or genetic engineering, or processed foods such as cereals, soups and drinks (Kaira, 2003).

Tomato-yogurt neutraceutical products were made by optimization of LAB probiotic fermented milk and tomato paste ratio to find the optimal composition with the highest lycopene content. The optimization was done by trying several compositions of fermented milk and tomato paste, which were then analyzed for their lycopene content using spectrophotometry method according to Nagata and Yamashita (1992).

\section{METHODS}

\section{Material and chemicals}

The tomatoes used were Lycopersicum esculentum or tomato fruit, obtained from the Karang Menjangan Market in Surabaya in one-time purchase to obtain a uniformity of the tomatoes condition. Based on the results of determination mophologically by Herbarium Malangiensis, tomatoes fruit used in this study (Figure 1) included the family Solanaceae, genus Lycopersicum, species of Lycopersicon esculentum Mill (Pratiwi, 2014). Dairy milk was obtained from the Jemursari dairy cow, Surabaya, Indonesia. The probiotic fermented milk was obtained from plain yogurt containing LAB Lactobacillus Acidophillus, Lactobacillus bulgaricus, and Lactobacillus casei production of Microbiology Practical Room Faculty of Pharmacy, Universitas Airlangga. N-hexane and acetone p.a (Merck) were used as solvents.

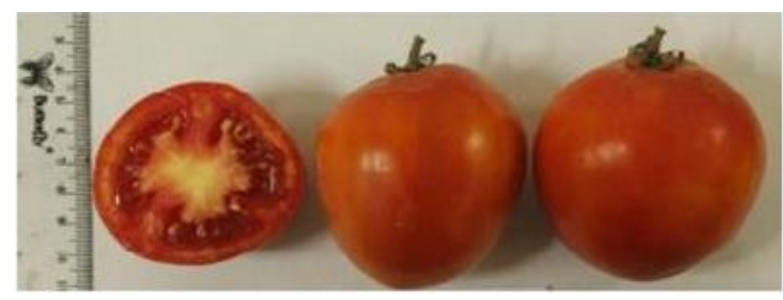

Figure 1. Tomato fruits

Preparation of probiotic fermented milktomato paste

The tomatoes fruits used in this research were specifically selected to be red both in outside and inside color, round shape with diameter of 7-10 cm, juicy texture and soursweet taste. As much as $2 \mathrm{~kg}$ of tomato fruits 
were washed, set aside to dry, and steamed for 10 minutes at $\pm 110^{\circ} \mathrm{C}$. The tomato rind was removed and the fruit was crushed with a blender. Tomato juice was made by the same manner without steaming. Yogurt or probiotic fermented milk was prepared by mixing 1 liter of pasteurized fresh cow's milk $\left(90^{\circ} \mathrm{C}, 15\right.$ minutes) with $25 \mathrm{~mL}$ plain yogurt containing a combination of LAB Lactobacillus bulgaricus, Lactobacillus casei, and Lactobacillus acidophilus $106-107 \mathrm{CFU} / \mathrm{mL}$ at $43^{\circ} \mathrm{C}$. The mixture was left to stand for 24 hours at room temperature $\left(30^{\circ} \mathrm{C}\right)$. Characteristics of the probiotic fermented milk were observed based on the acid $\mathrm{pH}$ and viscous texture. A mixture of the fermented milk-tomato pasta was made in 9 compositions $(\mathrm{g} / \mathrm{g}), 9: 1 ; 8: 2 ; 7: 3 ; 6: 4 ; 5: 5$; $4: 6 ; 3: 7 ; 2: 8 ; 1: 9$. Each combination was blended for homogenization.

\section{Extraction of lycopene}

Approximately 1 gram of each tomato juice, tomato paste, and fermented milktomato pasta at all composition were extracted with $8 \mathrm{~mL}$ acetone:n-hexane (4:6), then centrifuged $3000 \mathrm{x} \mathrm{g}$ for 10 minutes at $4^{\circ} \mathrm{C}$. The organic phase was separated after standing for 10 minutes and adding by $1 \mathrm{~mL}$ water. The organic phase was added by nhexane up to $10 \mathrm{~mL}$ and then dilution was done twice, before measurement by a spectrophotometer.

\section{Qualitatively and quantitatively analysis of lycopene}

The dilution results were measured quantitatively by spectrophotometer Agilent Technologies Cary $60 \mathrm{UV}-\mathrm{Vis}$ at wavelengths of 300-700 nm. Qualitative analysis of lycopene content was carried out by determination of the UV-Vis spectra profile of lycopene in a sample of tomato paste and probiotic fermented milk-tomato paste extract at 300-700 nm. Furthermore, quantitative analysis was done by measuring the absorbance at 663, 645, 505, and $453 \mathrm{~nm}$ using acetone-n-hexane (4:6) blank. The probiotic fermented milk extract in acetone-nhexane (4:6) was used as a blank for probiotic fermented milk-tomato paste analysis, in order to evaluate the effect of the probiotic fermented milk addition to lycopene in pasta or tomato juice. The lycopene levels were calculated using the formula proposed by Nagata and Yamashita (1992) as follows:

$[$ lycopene $](\mu \mathrm{g} / \mathrm{mL})=-0.0458 \times \mathrm{A} 663+0.2040 \times \mathrm{A} 645+0.3720 \times \mathrm{A} 505-0.0806 \times \mathrm{A} 453$ A663, A645, A505, A453, were absorbance at 663, 645, 505, and $453 \mathrm{~nm}$, respectively.

\section{RESULTS AND DISCUSSION}

The studies by Bunghez et al. (2011) and Alda et al. (2009) on the determination of lycopene in tomato and tomato products reported spectra profile of the lycopene extract from tomatoes samples in hexane indicated that profile of the spectra consisted of three peaks at 340, 245, and $506 \mathrm{~nm}$ respectively. Based on the spectrophotometric data analysis, the profiles of tomato paste and probiotic fermented milk-tomato paste were obtained as shown in Figures 3a and 3b. Tomato paste and yogurt-tomato paste showed the same spectra profile measured at wavelengths between 300 $700 \mathrm{~nm}$. There were three peaks detected and the maximum wavelength was obtained at 472 $\mathrm{nm}$. This phenomenon indicated that the spectra profile of the tomato pastes was similar to probiotic fermented milk-tomato paste qualitatively. The spectra profile of lycopene extract of Bunghez's and Alda's research's showed the similar profile as spectra extract of tomato paste and probiotic fermented milk-tomato paste. Alpha-carotene and lutein had maximum wavelengths at 420 $\mathrm{nm}$ and $444 \mathrm{~nm}$ (Bunghez, 2011), while the lycopene has a maximum wavelength of 470 and $500 \mathrm{~nm}$. Comparing with the profile of the probiotic fermented milk-tomato paste spectra, Bunghez's spectrum depicted peaks at $444 \mathrm{~nm}$, $470 \mathrm{~nm}$, and $502 \mathrm{~nm}$ with acetone:n-hexane $(1: 1, \mathrm{v} / \mathrm{v})$ solvents. On the other hands, Suwanaruang (2016) used hexane:ethanol: acetone $(2: 1: 1, \mathrm{v} / \mathrm{v} / \mathrm{v})$ as solvent and observed the lycopene extract at $503 \mathrm{~nm}$. In this study, we found three peaks at $446 \mathrm{~nm}, 472 \mathrm{~nm}$, and $502 \mathrm{~nm}$ (Figure 2). Alda et al. (2009) measured absorbance of the lycopene in n- 
hexane at 472 and $502 \mathrm{~nm}$. It can be seen that there was a shift in the wavelength of $2 \mathrm{~nm}$ might be due to differences in solvent composition. Djenni et. al. (2010) found that dichloromethane lycopene extract from tomato fruit showed three peaks at 457, 483, and 516 $\mathrm{nm}$ in hexane solvent. Absorbance at 483 was selected for determination of the lycopene.

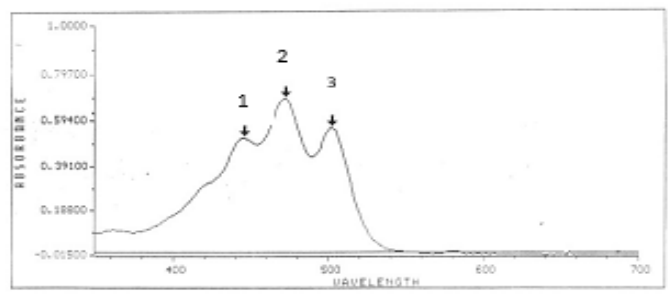

Figure 2. Spectra of yogurt-tomato paste scanned at $\lambda$ 400-700 nm. (1) $446 \mathrm{~nm}$, (2) $472 \mathrm{~nm}$, (3)502 nm
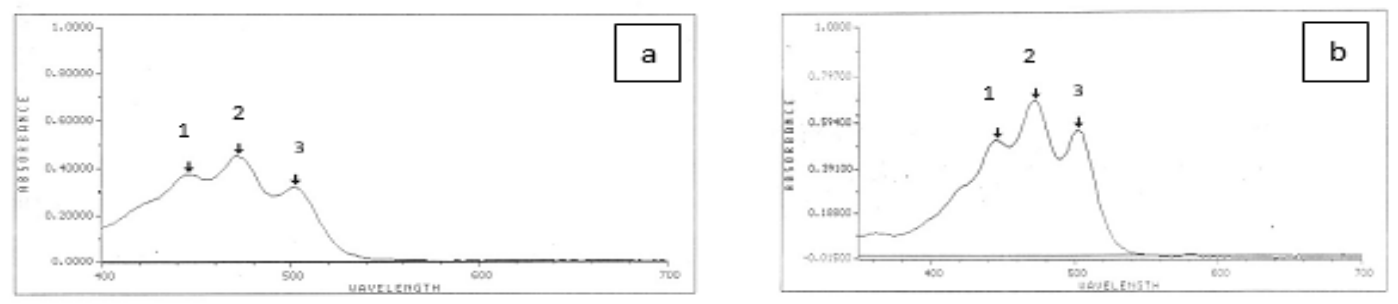

Figure 3. UV-Vis spectra of tomato paste (a) and tomato juice (b) scanned at $\lambda$ 400-700 nm. (1) $446 \mathrm{~nm}$, (2) 472 $\mathrm{nm}$, (3) $502 \mathrm{~nm}$

Calculations of lycopene levels in tomato juice, tomato paste, and probiotic fermented milk-tomato paste were based on the absorbance values at $663 \mathrm{~nm}, 645 \mathrm{~nm}, 505$ $\mathrm{nm}$, and $453 \mathrm{~nm}$ (Table I and Table II) following the method of Nagata and Yamashita (1992). All the composition of fermented milk and yogurt produced maximum absorption at $505 \mathrm{~nm}$, both on day 1 and 2 weeks after storage. Optimum composition was obtained on day 1 and 2 weeks after storage of 2:8 each then followed by $3: 7$. Profile of the lycopene levels for day 1 was different compared to spectra profile 2 weeks after storage. Decreased uptake on days 1 and 2 weeks after storage occurred in the ratio of 5:5 and 4:6, respectively, for a combination of fermented milk and tomato paste (Table III, Figure 4).

Table I. Absorbance of Sample Extract (first day)

\begin{tabular}{cccccc}
\hline No. & Sample & Fn1=663nm & Fn2=645nm & Fn3=505nm & Fn4=453nm \\
\hline 1 & BLANK & $-7.2 \mathrm{E}-04$ & -0.00122 & -0.00110 & -0.00108 \\
\hline 2 & Y:TP $=9: 1$ & 0.06888 & 0.06761 & 0.17310 & 0.15422 \\
\hline 3 & Y:TP $=8: 2$ & 0.08623 & 0.08516 & 0.27588 & 0.24934 \\
\hline 4 & Y:TP $=7: 3$ & 0.12714 & 0.12656 & 0.39714 & 0.35194 \\
\hline 5 & Y:TP $=6: 4$ & 0.16049 & 0.16457 & 0.53644 & 0.50517 \\
\hline 6 & Y:TP $=5: 5$ & 0.06808 & 0.06873 & 0.53687 & 0.46980 \\
\hline 7 & Y:TP $=4: 6$ & 0.09492 & 0.09697 & 0.56096 & 0.50552 \\
\hline 8 & Y:TP $=3: 7$ & 0.15346 & 0.15494 & 0.81306 & 0.71440 \\
\hline 9 & Y:TP $=2: 8$ & 0.15221 & 0.15500 & 1.1161 & 0.98357 \\
\hline 10 & Y:TP $=1: 9$ & 0.11249 & 0.11507 & 0.80241 & 0.76291 \\
\hline 11 & Tomato juice & -0.02861 & -0.03575 & 0.54292 & 0.47690 \\
\hline 12 & Tomato paste & 0.00862 & 0.00345 & 0.44748 & 0.48274 \\
\hline Y:
\end{tabular}

Y: TP was Yogurt: tomato paste

It was found that the highest lycopene content was found in probiotic fermented milk-tomato pasta with a composition of $2: 8$. The second highest content was found in the composition of 3:7. When converted, with the same number of samples, lycopene in probiotic fermented milk-tomato pasta with a ratio of $3: 7$ and $2: 8$ is higher than both tomato paste and tomato juice. It was estimated that there was interaction between yogurt and tomato paste; which causes lycopene levels to increase. The LAB might be contributed for 
the interaction, although the action mechanism of the interaction could not be understood. The effect of acid $\left(\mathrm{CO}_{2}\right)$ on the presence of lycopene has been reported by Helyes et al. (2011). The higher the $\mathrm{CO}_{2}$ concentration the lower the level of lycopene. In this research, the longer storage time, the higher the number of LAB cells, the more acidic the $\mathrm{pH}$, might increase the influence on lycopene content. Combination of LAB fermented milk - tomato paste 3:7 and 2:8 was the optimal composition, resulting in higher lycopene. Further investigation needs to be done to examine the mechanism of the $\mathrm{LAB}$ to increase the lycopene levels.

Table II. Absorbance of Sample (after two weeks)

\begin{tabular}{cccccc}
\hline No. & Sample & Fn1=663nm & Fn2=645nm & Fn3=505nm & Fn4=453nm \\
\hline 1 & BLANK & $7.2 \mathrm{E}-04$ & $4.3 \mathrm{E}-04$ & $9.2 \mathrm{E}-04$ & $8.5 \mathrm{E}-04$ \\
\hline 2 & Y:TP $=9: 1$ & -0.01102 & -0.01251 & 0.02681 & 0.02177 \\
\hline 3 & Y:TP $=8: 2$ & 0.06377 & 0.06558 & 0.38768 & 0.36409 \\
\hline 4 & Y:TP $=7: 3$ & 0.11874 & 0.12413 & 0.41507 & 0.40907 \\
\hline 5 & Y:TP $=6: 4$ & 0.02751 & 0.02632 & 0.42239 & 0.36458 \\
\hline 6 & Y:TP $=5: 5$ & -0.01244 & -0.01270 & 0.33188 & 0.28586 \\
\hline 7 & Y:TP $=4: 6$ & 0.01268 & 0.00880 & 0.18983 & 0.16942 \\
\hline 8 & Y:TP $=3: 7$ & 0.05418 & 0.05327 & 0.45279 & 0.41934 \\
\hline 9 & Y:TP $=2: 8$ & 0.10034 & 0.09859 & 0.63196 & 0.56865 \\
\hline 10 & Y:TP $=1: 9$ & -0.04057 & -0.04414 & 0.31941 & 0.27258 \\
\hline
\end{tabular}

Y:TP was Yogurt: tomato paste

The same results were shown in the observation of LAB fermented milk-tomato paste after storage for 14 days. However, there was a decrease of lycopene content in several compositions after storage. Acidity ( $\mathrm{pH} 4-5.5)$ and concentration of the LAB fermented milk were critical factors that affected the lycopene concentration in the tomato-paste. At a ratio of LAB fermented milk and tomato pasta 9:1, the lycopene level decreased dramatically after 14 days storage. Alda et al. (2009) reported that lycopene content of tomatoes remained high during the multistep processing operations for the production of juice and paste. Kaur et al.
(2016) found that the fermented tomato juice could be used as a raw material for LAB fermentation. Stability of lycopene against degradation is affected by long heating time or at temperature above $50^{\circ} \mathrm{C}$ (Lambelet et al., 2009). The lycopene will undergo isomerization under several conditions, such as heat, acids and light (Xianquan et al., 2005). Degradation proceeds faster than isomerization at temperature above $50^{\circ} \mathrm{C}$. This phenomenon is very interesting for future investigation to obtain an ideal formula with high lycopene content and antioxidant activities.

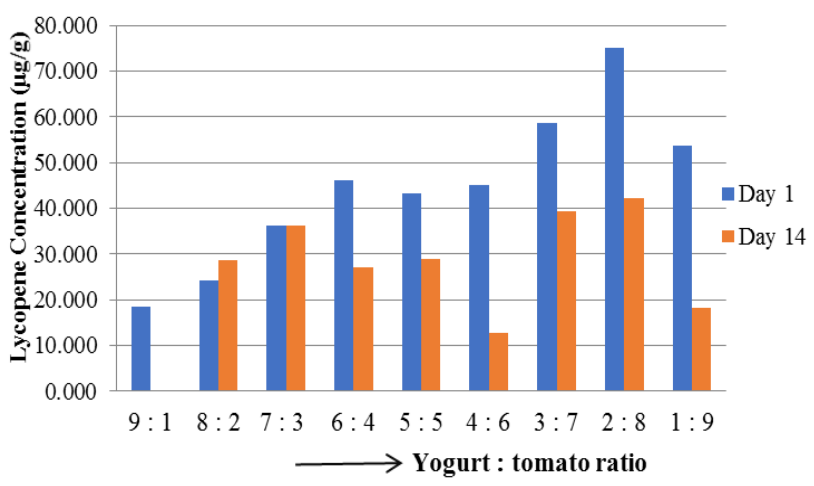

Figure 4. Lycopene content in yogurt-tomato paste

Lycopene content in tomato paste was higher than lycopene content in tomato fruit (Alda et al., 2009), but in this study, lycopene content in tomato juice was higher than tomato paste. Lycopene is known to exist in a variety of isomeric forms, including the all-trans, mono-cis, and poly-cis forms. The all-trans isomer is the predominant geometrical isomer 
in fresh tomatoes. All-trans-isomer lycopene $\left(\mathrm{C}_{40} \mathrm{HS}_{6}\right)$ is an acyclic, open chain polyene hydrocarbon with 13 double bonds, of which 11 are conjugated in a linear array, but 7 bonds can isomerize from the trans-form to the mono or poly-cis form under the influence of heat, light, and certain chemical reactions $(\mathrm{Su}$ et al. 2002).

Table III. Lycopene Content in Yogurt-Tomato

\begin{tabular}{ccc}
\hline $\begin{array}{c}\text { Ratio of } \\
\text { Yogurt-Tomato } \\
\text { paste }\end{array}$ & \multicolumn{2}{c}{ Lycopene content } \\
\cline { 2 - 3 } & Day-1 $(\boldsymbol{\mu g} / \mathbf{g})$ & Day-14 $(\boldsymbol{\mu g} / \mathbf{g})$ \\
\hline $9: 1$ & 1.8491 & 0.1383 \\
\hline $8: 2$ & 2.4232 & 2.8751 \\
\hline $7: 3$ & 3.6174 & 3.6213 \\
\hline $6: 4$ & 4.6011 & 2.7003 \\
\hline $5: 5$ & 4.3300 & 2.8937 \\
\hline $4: 6$ & 4.5090 & 1.2614 \\
\hline $3: 7$ & 5.8652 & 3.9372 \\
\hline $2: 8$ & 7.4993 & 4.2116 \\
\hline $1: 9$ & 5.3730 & 1.8299 \\
\hline Fresh tomato $=3.7568 \mu \mathrm{g} / \mathrm{g} ;$ Tomato paste $=2.8194 \mu \mathrm{g} / \mathrm{g}$
\end{tabular}

Takeoka et al. (2001) studied processing effects of lycopene content in tomato and found that sample of raw tomatoes and tomato juice after adding hot scalding water and final paste indicated that the lycopene losses (9$28 \%$ ) during processing into final paste. Isomerization and oxidation would degrade lycopene; by which its bioactivity is reduced. The lycopene oxidation and isomerization of all-trans form to cis form are induced by heat and light. Su et al., (2002) have investigated the effects of thermal treatment and light irradiation on the stability of the lycopene. It has been found that lycopene stability depends on the extent of oxidation and isomerization. Cis-isomers are less stable than trans-isomers, conformed to studies results reported by Gupta et al. (2010). The major effect of thermal treatment and light irradiation was a significant decrease in the total lycopene content (Su et al. 2002). Honda et al. (2017) reported that Z-isomers of lycopene increased by thermal treatment at $120^{\circ} \mathrm{C}$ and $150^{\circ} \mathrm{C}$ for 1 hour to $10.0 \%$ and $56.2 \%$, respectively.

This research was a preliminary study to obtain the tomato- yogurt paste composition with the most maximal lycopene content. Further investigations are needed to determine the probiotic fermented milk-tomato formula with the most optimal antioxidant activity with lycopene and other component content of the formula. Wang et al. (2017) reviewed antioxidant activities showing some LAB, such as Bifidobacterium animalis, Lactobacillus plantarum, and Lactobacillus rhamnosus, although the mechanisms have not been completely understood. It was also found that there was a decrease in the amount of lycopene in the probiotic fermented milktomato paste after storage for two weeks, therefore in the next study it is necessary to investigate the effect of storage time on the lycopene levels and antioxidant activity of probiotic fermented milk-tomatoes products.

\section{CONCLUSION}

The highest content of lycopene was found in probiotic or LAB fermented milktomato paste $2: 8$. The lycopene content was higher than lycopene in tomato paste and tomato juice without addition of the probiotic fermented milk.

\section{ACKNOWLEDGEMENT}

The author is grateful to Department of Pharmaceutical Chemistry, Faculty of Pharmacy, Universitas Airlangga for providing mixed culture LAB starter.

\section{REFERENCES}

Anonim, 2009. Standar Nasional Indonesia, 7388. Badan Standarisasi Nasional. ICS 67.220.20 Jakarta.

Alda, L.M., Gogoasa, I., and Bordean, D.M., 
2009. Lycopene content of tomatoes and tomato products. Journal of Agroalimentary Processes and Technologies, 15(4), 540-542.

Djenni, Z.C., Ferhat, M.A., Tomao, V., and Chemat, F., 2010. Carotenoid extraction from tomato using a green solvent resulting from orange processing waste. Journal of Essential Oil Bearing Plants, 13(2), 139-147.

Erge, H.S., and Karadeniz, F., 2011. Bioactive compounds and antioxidant activity of tomato cultivar. International Journal of Food Properties, 14(5), 968-977.

Gupta, R., L.A., Basubramaniam, V.M., Steven, J.S., and David, M.F., 2010. Storage stability of lycopene in tomato juice subjected to combined pressureheat treatments. Journal of Agriculture and Food Chemistry, 58(14), 83058313.

Helyes, L., Lugasi, A., Péli, E, and Pek, Z., 2011. Effect of elevated $\mathrm{CO}_{2}$ on lycopene content of tomato (Lycopersicon lycopersicum L. Karsten) fruits. Acta Alimentaria, 40(1), 80-86.

Hidayah, I.R., Erma, N., and Isnaeni, 2014. Daya hambat kombinasi susu probiotik (Lactobacillus acidophilus and Lactobacillus bulgaricus) dan pasta tomat terhadap Escherichia coli dan Staphylococcus aureus. Berkala Ilmiah Kimia Farmasi, 3(1), 36-40.

Honda, M., Kageyama, H., Hibino, T., Takemura, R., Goto, M., and Fukaya, T., 2017. Thermal isomerization pretreatment to improve lycopene extraction from tomato pulp. Food Science and Technology, 86, 69-75.

Isnaeni, Kusumawati, I., Sugiyartono, and Rizal, M.A.S., 2016. Efek imunomodulator kombinasi susu probiotik (Lactobacillus acidophillus) dan ekstrak daun jambu biji. Jurnal Farmasi Indonesia, 8(1), 277-282.

Isnaeni and Mertaniasih, N.M., 2015. Antibacterial activities of probiotics mixed culture against methicillin resistant Staphylococcus aureus
(MRSA) and Extended Spectrum Beta Lactamase (ESBL) Bacteria. Journal of Chemical and Pharmceutical Research, 7(4), 1005-1010.

Kaira, E.K., 2003. Nutraceutical-definitionand introduction. AAPS Pharm.Sci., 5(3): E25.

Karakaya, S., and Yilmaz, N., 2007. Lycopene content and antioxidant activity of fresh and processed tomatoes and in vitro bioavailability of lycopene. J. Sci. Food and Agric., 87, 2342-2347.

Kaur, S., Kaur, H.P., and Grover, J., 2016. Fermentation of tomato juice by probiotic Lactic acid bacteria. Int. J Adv. Pharm. Biol. Chem., 5(2), 311319.

Lambelet, P., Myriam, R., Karlheinz, B., Federico, F., and Andreea, M.G., 2009. Improving the stability of lycopene Zisomers in isomerized tomato extracts. Food Chemistry, 112 (Issue 1), 156161.

Nagata M and Yamashita I., 1992. Simple Method for Simultaneous determination of chlorophyll and carotenoids in tomato fruits. Jpn Soc. Food Sci. Technol., 39, 925-928.

Pratiwi, W.D., 2014. Perbandingan aktivitas antioksidan tomat sayur, tomat ceri, dan tomat buah terhadap 1,1-diphenyl2-picrylhydrazil (DPPH). Fakultas Farmasi Universitas Airlangga Surabaya.

Rajarajan, P., Amudha, K., Gupta, R., LABiyan, S., Prasad, G., Tejaswini, M., and Kumar, K.V., 2018. In vitro evaluation of antimicrobial activity and probiotic potential of Lactobacillus strains against some human pathogen. Recent Res. Sci. Technol. 10, 31-35.

Sholeha, A, Purwanti, T., and Isnaeni., 2014. Pengaruh konsentrasi natrium alginate terhadap viabilitas Lactobacillus spp. dan aktivitas antibakteri sediaan mikropartikel kombinasi probiotikpasta tomat, PharmaScientia, 3(1).

Soccol, C.R., Vandenberghe, L.P.S., Spier, M.R., Medeiros, A.B.P., Yamaguishi, C.T., Lindner, J.D.D., Pandey, A., and 
Soccol, V.T., 2010. The potential of probiotics: a Review. Food. Technol. Biotechnol., 48(4), 413-434.

$\mathrm{Su}, \mathrm{J} ., \mathrm{Wu}, \mathrm{Y}$, Bryan, M., and Le Magner, M., 2002. Oxidation and isomerization of lycopene under thermal treatment and light irradiation in food processing. Nutraceutical and Food, 7 , 179-183.

Sugiyartono, Pamuji, D., A., Antono, A., Kusumawati, I., and Isnaeni., 2014. Physical characteristic and viability of Lactobacillus acidophilus micro particle using HPMC K1001V and HPMC K4M as matrices. Int. J. Pharm.Pharm. Sci., 6 (Suppl 2), 296298.

Suwanaruang, T., 2016. Analysing lycopene content in fruit. Agriculture and Agricultural Science Procedia, 11, 4648.

Takeoka, G.R., Dao, L., Flessa, S., Gillespie, G.M., Jewell, W.T., Huebner, B., Bertow, D., and Ebeler, S.E., 2001. Processing Effects of lycopene content and Antioxidant Activity of Tomatoes. J. Agric. Food Chem., 49(8), 37133717

Wang, Y., Wu, Y., Wang, Y., Xu, H., Mei, X., Yu, D., Wang. Y, and Li, W., 2017. Antioxidant properties of probiotic bacteria. Nutrients, 9, 521, 1-15.

Xianquan,S., Shi, J., Kakuda, Y., and Yueming, J., 2005. Stability of lycopene during food processing and storage. J. Med.Food, 8, 413-422. 